\title{
Pengaruh Hepatokuratif Ekstrak Daun Kenikir (Cosmos caudatus) terhadap Kadar SGPT Tikus Wistar yang Diinduksi Parasetamol
}

\author{
Syaema Maulida ${ }^{1}$, Yanuarita Tursinawati ${ }^{1}$, Ardhea Jaludamascena ${ }^{1}$ \\ ${ }^{\text {I}}$ Fakultas Kedokteran Universitas Muhammadiyah Semarang
}

Email: yanuarita_tursina@unimus.ac.id

\begin{abstract}
The use of high doses of paracetamol triggers liver damage which is characterized by an increase in SGPT. Kenikir leaves contain flavonoids, saponins, and tannins which function as hepatocuratives. The purpose of this study is to determine the effect of kenikir leaf extract on SGPT levels in the blood of wistar strain induced by paracetamol. This research was a laboratory experimental study with a post test only control group design. Samples of 30 male Wistar strain rats were divided into 5 groups randomly. The treatment was carried out for 15 days, the K-group was only given standard food during the treatment period, the KT group was induced by a single dose of paracetamol 270mg / 200grBB without any intervention, the $\mathrm{K}+$, PI, and PII groups were induced by paracetamol, $\mathrm{K}+$ was given $\mathrm{N}$-acetylcysteine $2.52 \mathrm{mg} / \mathrm{kgBW}$, PI was given $62.5 \mathrm{mg} / \mathrm{kgBW}$ kenikir leaf extract, PII $125 \mathrm{mg} / \mathrm{kgBW}$ kenikir leaf extract until the 14th day and the 15th day was examined for SGPT levels. Analyze data used one-way ANOVA test and continued by Post-hoc. The mean SGPT levels were K-47.0 $\pm 0.82 \mathrm{IU} / \mathrm{L}, \mathrm{KT} 78.0 \pm 0.97 \mathrm{IU} / \mathrm{L}, \mathrm{K}+40.2 \pm 2.27 \mathrm{IU} / \mathrm{L}, \mathrm{PI} 55.3 \pm$ $1.74 \mathrm{IU} / \mathrm{L}$, and PII $69.3 \pm 1.48 \mathrm{IU} / \mathrm{L}$. There waw significant differences in the average SGPT between all groups (p $=0,000)$. Significant differences were also found between groups $K$ - with KT $(p=0,000)$, K- with $K+(p=0.023)$, Kwith P1 ( $p=0.001), K$ - with P2 ( $p=0,000), K T$ with $\mathrm{K}+(\mathrm{p}=0,000), \mathrm{KT}$ with P1 $(\mathrm{p}=0,000), \mathrm{KT}$ with P2 (p=0,000), $\mathrm{K}+$ with P1 ( $=0,000), \mathrm{K}+$ with P2 ( $\mathrm{p}=0,000)$, and P1 with P2 ( $=0,000)$. Kenikir leaf extract (Cosmos caudatus) can affect SGPT levels in the blood of rats wistar-induced paracetamol.
\end{abstract}

Keyword : kenikir leaves, parasetamol, SGPT

\section{Abstrak}

Penggunaan parasetamol dosis tinggi menjadi pemicu kerusakan hepar yang ditandai dengan peningkatan SGPT. Daun kenikir mengandung flavonoid, saponin, dan tanin yang berfungsi sebagai hepatokuratif. Tujuan penelitian ini adalah untuk mengetahui pengaruh ekstrak daun kenikir terhadap kadar SGPT darah tikus galur wistar yang diinduksi parasetamol. Penelitian ini merupakan studi eksperimen laboratorium dengan rancangan post test only control group design. Sampel sebanyak 30 ekor tikus jantan galur wistar yang dibagi dalam 5 kelompok secara random. Perlakuan dilakukan selama 15 hari, kelompok K- hanya diberi pakan standar selama masa perlakuan, kelompok KT diinduksi parasetamol dosis tunggal 270mg/200grBB tanpa diberikan intervensi, kelompok $\mathrm{K}+$, PI, dan PII diinduksi parasetamol, $\mathrm{K}+$ diberi $\mathrm{N}$-asetilsistein $2,52 \mathrm{mg} / \mathrm{kgBB}$, PI diberi ekstrak daun kenikir $62,5 \mathrm{mg} / \mathrm{kgBB}$, PII ekstrak daun kenikir $125 \mathrm{mg} / \mathrm{kgBB}$ sampai hari ke-14 dan hari ke-15 diperiksa kadar SGPT. Analisa data dengan uji one-way

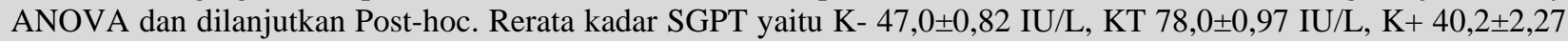
IU/L, PI 55,3 $\pm 1,74$ IU/L, dan PII 69,3 $\pm 1,48$ IU/L. Terdapat perbedaan signifikan rerata SGPT antar seluruh kelompok $(\mathrm{p}=0,000)$.Perbedaan signifikan juga ditemukan antar kelompok $\mathrm{K}$ - dengan $\mathrm{KT}(\mathrm{p}=0,000), \mathrm{K}-$ dengan $\mathrm{K}+(\mathrm{p}=0,023)$, $\mathrm{K}$ - dengan P1 ( $\mathrm{p}=0,001), \mathrm{K}$ - dengan $\mathrm{P} 2(\mathrm{p}=0,000), \mathrm{KT}$ dengan $\mathrm{K}+(\mathrm{p}=0,000), \mathrm{KT}$ dengan $\mathrm{P} 1(\mathrm{p}=0,000), \mathrm{KT}$ dengan $\mathrm{P} 2$ $(\mathrm{p}=0,000), \mathrm{K}+$ dengan $\mathrm{P} 1(\mathrm{p}=0,000), \mathrm{K}+$ dengan $\mathrm{P} 2(\mathrm{p}=0,000)$, dan $\mathrm{P} 1$ dengan $\mathrm{P} 2(\mathrm{p}=0,000)$. Ekstrak daun kenikir (Cosmos caudatus) dapat mempengaruhi kadar SGPT darah tikus galur wistar yang diinduksi parasetamol.

Keyword : daun kenikir, parasetamol, SGPT 


\section{PENDAHULUAN}

Prevalensi hepatitis di indonesia pada tahun 2013 dua kali lebih tinggi dibandingkan tahun 2007(1,2\%), dengan prevalensi tertinggi adalah nusa tenggara timur $(4,3 \%)$, papua $(2,9 \%)$, Sulawesi selatan (2,5\%), maluku (2,3\%), dan Jawa tengah (1\%). ${ }^{1}$ Hepatitis adalah peradangan pada sel hati yang disebabkan oleh infeksi, konsumsi alkohol, lemak yang berlebihan, penyakit autoimun, dan drug induced liver hepatotoxicity ${ }^{2,3,4,5}$. Salah satu drug induced liver injury adalah parasetamol.

Parasetamol dimetabolisme oleh hepar melalui 3 jalur, yaitu glukuronidasi, sulfasi, dan melalui mekanisme oksidatif enzim sitokrom hepatik P 450. Mekanisme oksidatif enzim sitokrom P-450, parasetamol dikonversi menjadi metabolit toxic reaktif $N$-acetyl-p-benzoquinoneimine (NAPQI) ${ }^{6}$. Kondisi overdosis, GSH habis lebih cepat daripada yang bisa diregenerasi serta memicu peningkatan Reactive Oxygen Spesies (ROS) di sel hepatosit dan NAPQI, kemudian terakumulasi membentuk ikatan kovalen dengan protein atau asam nukleat hepatosit sehingga menyebabkan nekrosis ${ }^{6,7}$.

Salah satu petanda kerusakan hepar, termasuk karena parasetamol adalah kenaikan kadar Serum glutamic pyruvic transaminase $\left(\right.$ SGPT) ${ }^{8}$. SGPT adalah enzim sitosol yang banyak ditemukan di hepar. Kadar SGPT dalam serum menjadi petunjuk yang lebih spesifik terhadap kerusakan hepar ${ }^{9}$

Mengatasi terjadinya hepatotoksisitas akibat parasetamol dilakukan pemberian $\mathrm{N}$-asetilsistein (NAC) sebagai hepatokuratif atau obat pilihan utama. $N$ asetilsistein secara cepat dapat dihidrolisis menjadi sistein yang merupakan prekusor $\mathrm{GSH}^{10}$. WHO mendukung upaya peningkatan keamanan dan khasiat dari obat bahan alam karena secara umum lebih aman dan efek samping yang lebih sedikit daripada obat sintetik. Salah satu tanaman yang berkhasiat sebagai obat seperti tanaman kenikir (Cosmos caudatus). Secara tradisional daun ini juga digunakan sebagai obat penambah nafsu makan dan mengurangi rasa mual ${ }^{11}$.

Ekstrak daun kenikir mengandung flavonoid, saponin dan $\operatorname{tanin}^{12}$. Flavonoid diketahui dapat meningkatkan kadar $\mathrm{GSH}^{13}$. Selain itu, juga dapat memicu penurunan sitokin proinflamasi seperti TNF- $\alpha$, IL-1, dan IF- $\gamma$ serta meningkatkan sitokin antiinflamasi seperti IL-6 dan IL-10 yang berperan penting dalam regenerasi sel hepar, aktivitas ini mengarah pada perbaikan jaringan setelah reaksi peradangan dapat dikendalikan ${ }^{14,15}$. Perbaikan jaringan hepar dapat dilihat dari penurunan nilai kadar SGPT yang mana sebagai parameter spesifik fungsi hepar.

Penelitian daun kenikir belum banyak dilakukan, sehingga peneliti tertarik untuk melakukan penelitian khususnya mengenai pengaruh hepatokuratif dari daun kenikir. Penelitian ini bertujuan untuk mengetahui pengaruh hepatokuratif ekstrak daun kenikir (Cosmos caudatus) terhadap kadar SGPT darah tikus galur wistar yang diinduksi parasetamol.

\section{METODE}

Penelitian dilakukan di Laboratorium Biologi Fakultas Matematika dan Ilmu Pengetahuan Alam (FMIPA) Universitas Negeri Semarang (UNNES). Jenis penelitian ini adalah eksperimen laboratorik dengan rancangan post test only control group design. Jumlah sampel 30 ekor tikus galur wistar yang memenuhi kriteria inklusi: berjenis kelamin jantan, berat badan 150-200 gram, berusia 2-3 bulan, sehat secara klnis (bergerak aktif, tidak cidera, dan tidak luka) serta kriteria eksklusi tikus yang tidak sakit (tidak aktif, tidak mau makan dan minum). Sampel akan dibagi menjadi 5 kelompok masing-masing terdiri dari 5 ekor tiap kelompok dan tambahan 1 ekor tikus tiap kelompok untuk mengantisipasi adanya kriteria drop out selama masa perlakuan. Kelompok kontrol negatif (K-) yang hanya diberikan pakan standar selama masa perlakuan, kontrol teknik (KT) diberikan parasetamol dosis tunggal 
270mg/200grBB tanpa diberikan intervensi, kontrol positif $(\mathrm{K}+)$ diberikan parasetamol dosis tunggal $270 \mathrm{mg} / \mathrm{kgBB}$ dan $N$-acetylsistein $2,52 \mathrm{mg} / 200 \mathrm{grBB}$ per hari, perlakuan 1 (P1) diberikan ekstrak daun kenikir $62,5 \mathrm{mg} / \mathrm{kgBB}$ per hari, dan perlakuan 2 (P2) diberikan ekstrak daun kenikir $125 \mathrm{mg} / \mathrm{kgBB}$ per hari. Masingmasing kelompok diberikan selama 14 hari. Analisis data menggunakan One way ANOVA.

\section{HASIL}

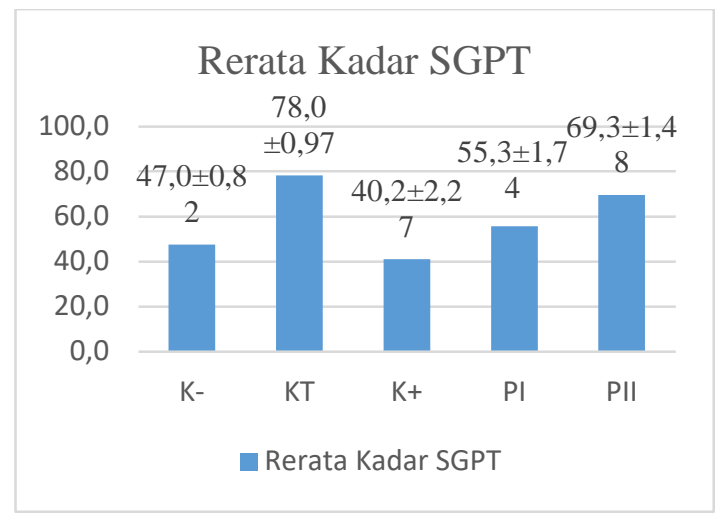

Gambar 1. Diagram batang rata-rata kadar SGPT

Gambar 1. menunjukkan nilai rerata kadar SGPT kelompok kontrol teknik (KT) 78,0 IU/L yang mempunyai kadar terbesar dibandingkan nilai rata-rata kelompok kontrol negatif (K-) 47,0, kelompok kontrol positif (K+) 40,2 IU/L, kelompok perlakuan 1 (PI) 55,3 IU/L, dan kelompok perlakuan 2 (PII) 69,3 IU/L.

Hasil uji normalitas (uji Shapiro-Wilk) terhadap semua kelompok perlakuan diperoleh $p>0,05$ dan uji homogenitas (uji Lavene) didapatkan nilai $p<$ 0,05 $(\mathrm{p}=0,037)$. Dapat disimpulkan bahwa data berdistribusi normal dan varian tidak homogen.

Varian data yang tidak homogen dilanjutkan dengan uji transformasi. Setelah dilakukan uji transformasi ternyata varian menjadi homogen yaitu $\mathrm{p}=0,129$ yang artinya data dapat dilanjutkan dengan menggunakan uji parametrik One Way ANOVA. Dari hasil analisa uji One Way ANOVA didapatkan p=0,000 yang artinya terdapat perbedaan yang signifikan antar kelompok . Guna mengetahui perbedaan antar kelompok, maka analisis dilanjutkan dengan menggunakan uji Post Hoc LSD.

Berdasarkan hasil analisis statistik uji Post Hoc LSD menunjukkan bahwa terdapat perbedaan yang signifikan antara kelompok K- dengan KT ( $\mathrm{p}=0,000)$, Kdengan $\mathrm{K}+(\mathrm{p}=0,023)$, K- dengan $\mathrm{P} 1(\mathrm{p}=0,001)$, Kdengan P2 $(\mathrm{p}=0,000)$, KT dengan $\mathrm{K}+(0,000)$, KT dengan P1 ( $\mathrm{p}=0,000)$, KT dengan P2 $(\mathrm{p}=0,000), \mathrm{K}+$ dengan P1 (0,000), K+ dengan P2 ( $\mathrm{p}=0,000)$, dan P1 dengan P2 ( $\mathrm{p}=0,000)$ seperti pada tabel 1 .

Tabel 1. Perbedaan Pengaruh Hepatokuratif Ekstrak Daun Kenikir (Cosmos caudatus) terhadap Kadar SGPT Tikus Wistar yang Diinduksi Parasetamol

\begin{tabular}{|c|c|c|c|c|c|c|}
\hline Kelo & \multirow{2}{*}{$\begin{array}{c}\text { One } \\
\text { Way } \\
\text { ANO } \\
\text { VA }\end{array}$} & \multicolumn{3}{|c|}{ Post Hoc } & \multirow[b]{2}{*}{ P1 } & \multirow[b]{2}{*}{$\mathrm{P} 2$} \\
\hline $\begin{array}{c}\text { mpo } \\
\text { k } \\
\text { Perla } \\
\text { kuan }\end{array}$ & & K- & KT & $\mathrm{K}+$ & & \\
\hline K- & \multirow{5}{*}{0,000} & - & 0,000 & 0,023 & 0,001 & 0,000 \\
\hline KT & & 0,000 & - & 0,000 & 0,000 & 0,000 \\
\hline $\mathrm{K}+$ & & 0,023 & 0,000 & - & 0,00 & 0,000 \\
\hline $\mathrm{P} 1$ & & 0,001 & 0,000 & 0,000 & - & 0,000 \\
\hline $\mathrm{P} 2$ & & 0,000 & 0,000 & 0,000 & 0,000 & - \\
\hline
\end{tabular}

\section{PEMBAHASAN}

Hasil rerata kadar SGPT tertinggi yaitu pada kelompok KT. Pada kelompok KT tikus galur wistar hanya diinduksi parasetamol dengan dosis toksik tanpa diberikan intervensi, hal ini menunjukkan bahwa pemberian dosis toksik dapat menaikkan kadar SGPT. Parasetamol dosis toksik meningkatkan aktivitas mekanisme oksidatif enzim sitokrom P-450 dan menghasilkan metabolit toxic rekatif $N$-acetyl-pbenzoquinoneimine berlebih. NAPQI secara efisien akan didetoksifikasi oleh glutathion (GSH), tetapi pada dosis toksik atau berlebih GSH tidak mampu mengikat seluruh NAPQI yang kemudian NAPQI akan terakumulasi dan membentuk ikatan kovalen dengan protein serta asam nukleat hepatosit ${ }^{6,7}$. Rendahnya GSH 
juga meningkatkan respon stres oksidatif, sehingga terjadi gangguan fungsi pada mitokondria yang pada akhirnya terjadi kerusakan sel atau nekrosis yang mengakibatkan peningkatan kadar enzim SGPT ${ }^{16,17,18}$.

Kadar SGPT kelompok K+ lebih rendah secara signifikan terhadap kadar SGPT kelompok KT. Dimana pada kelompok KT diberikan intervensi berupa $N$-acetylsistein dosis 2,52mg/kgBB. Hal ini menunjukkan bahwa kerusakan yang terjadi pada struktur hepar tikus galur wistar akibat induksi parasetamol dosis toksik dapat diperbaiki dengan pemberian $\mathrm{N}$-acetylsistein. $\mathrm{N}$-asetilsistein merupakan antidotum untuk keracunan parasetamol yang berfungsi meningkatkan kadar glutathion sehingga yang aktif akan mengikat NAPQI dan $\mathrm{N}$-Asetilsistein berperan mencegah berikatannya NAPQI dengan hepatosit, sehingga mencegah terjadinya hepatotoksisitas ${ }^{19}$.

Rerata kadar SGPT kelompok P1 dan P2 lebih rendah secara signifikan daripada kelompok KT. Hal ini menunjukkan bahwa kerusakan hepar akibat induksi parasetamol dosis toksik dapat dikurangi dengan pemberian ekstrak daun kenikir. Pada penelitian kali ini dosis ekstrak daun kenikir yang digunakan yaitu $62,5 \mathrm{mg} / \mathrm{kgBB}$ pada PI dan $125 \mathrm{mg} / \mathrm{kgBB}$ pada PII. Pada ekstrak daun kenikir dengan kandungan flavonoid, saponin, dan tanin dimana kandungan ini dapat meningkatkan glutathion ${ }^{12,13}$. Glutathion adalah tripeptida ( $\gamma-L-$ Glutamil - L - sisteinil - glisin) yang berfungsi sebagai antioksidan dan berperan penting dalam pertahanan sel tubuh terhadap pengaruh radikal bebas, selain itu juga akan menekan aktifitas sel Kuffer dalam produksi TNF-a dalam memicu kerusakan pada jaringan hepar dan meningkatkan produksi IL-10 yang dapat memacu regenerasi sel hepar yang rusak akibat overdosis parasetamol ${ }^{14,15}$.

Hal ini sejalan dengan penelitian sebelumnya, dimana ekstrak daun kenikir yang diberikan pada tikus galur wistar dengan dosis 49,5 mg,
$79 \mathrm{mg}$, dan $158 \mathrm{mg}$ selama 14 hari dapat melindungi atau sebagai hepatoprotektor dari penggunaan parasetamol dosis toksik ${ }^{21}$. Pemberian fraksi etil asetat kenikir dengan dosis $281,25 \mathrm{mg} / \mathrm{kgBB}, 562,5 \mathrm{mg} / \mathrm{kgBB}$, dan $1.125 \mathrm{mg} / \mathrm{kgBB}$ mampu menekan kenaikan kadar SGPT pada tikus galur wistar yang diinduksi parasetamol $^{19}$.

Pengaruh ekstrak daun kenikir perlu diperhatikan bahwa hubungan dosis dan efeknya tidak selalu positif yang artinya semakin tinggi dosis tidak selalu diikuti dengan pengaruh yang semakin baik ${ }^{20}$. Uji statistik menunjukkan perbedaan bermakna pada rerata kadar SGPT antara PI dengan PII. Pada dosis $62,5 \mathrm{mg} / \mathrm{kgBB}$ lebih efektif dalam menurunkan kadar SGPT dari pada PII dengan dosis $125 \mathrm{mg} / \mathrm{kgBB}$. Hubungan dosis dan respon obat sangat terkait dengan ketersediaan dan karakteristik reseptor dalam menimbulkan efek. Penurunan efek pada dosis yang lebih tinggi menunjukkan terjadinya kejenuhan reaksi antar molekul dengan reseptornya sehingga peningkatan dosis tidak akan menyebabkan peningkatan efek yang timbul. Ekstrak daun kenikir memiliki kandungan banyak zat aktif, diduga diantaranya memiliki kemiripan gugus aktif sehingga dapat berikatan dengan reseptor yang sama untuk menimbulkan efek yang sinergis maka efek kejenuhan lebih cepat terlihat ${ }^{21}$. Adapun flavonoid yang merupakan salah satu kandungan daun kenikir akan diabsorbsi di usus halus dan akan memasuki vena porta. Dalam vena porta selanjutnya flavonoid akan dimetabolisme lagi di hepar dan diubah menjadi bentuk O-methylated, sulphates, dan glucuronides yang akan masuk ke dalam darah dan menuju sel target berfungsi melawan kematian sel yang diinduksi oleh hidrogen peroksida $^{22}$. Pemberian dosis tinggi memungkinkan hepar bekerja lebih, sehingga proses metabolisme berkurang dan memberikan pengaruh yang minimal.

Kelemahan dalam penelitian ini, dimana rancangan penelitian yang digunakan adalah Post test 
only control group design, sehingga peneliti tidak dapat menilai kondisi hepar yang dilihat dari kadar SGPT sebelum perlakuan. Selain itu, Peneliti tidak melakukan identifikasi kadar zat aktif yang paling efektif sebagai antioksidan pada ekstrak daun kenikir.

\section{SIMPULAN}

Berdasarkan penelitian yang telah dilakukan dapat disimpulkan bahwa terdapat pengaruh hepatokuratif ekstrak daun kenikir (Cosmos caudatus) terhadap kadar SGPT pada tikus galur wistar yang diinduksi parasetamol. Pemberian ekstrak daun kenikir (Cosmos caudatus) dengan dosis $62,5 \mathrm{mg} / \mathrm{kgBB}$ lebih efektif dalam menurunkan kadar SGPT pada tikus galur wistar (Rattus novergicus) dibandingkan dengan dosis $125 \mathrm{mg} / \mathrm{kgBB}$

\section{DAFTAR PUSTAKA}

1. Pusat Data dan Informasi Kementerian Kesehatan RI. Situasi dan analisis hepatitis. 2013

2. Iida-Ueno A, Enomoto M, Tamori A, Kawada N. Hepatitis B virus infection and alcohol consumption. World J Gastroenterol 2017;23 (15):2651-9.

3. Green CJ, Hodson L. The influence of dietary fat on liver fat accumulation. Nutrients. 2014;6 (11):501833.

4. Enomoto H, Nishiguchi S. Similarities and differences in autoimmune hepatitis epidemiology between east and west: autoimmune hepatitis in east asia, southeast asia, and south asia. Inflamm Intest Dis. 2016;1 (4):150-8.

5. Devarbhavi H. An update on drug-induced liver injury. J Clin Exp Hepatol. 2012;2 (3):247-59.

6. Yoon E, Babar A, Choudhary M, Kutner M, Pyrsopoulos N. Acetaminophen-induced hepatotoxicity: a comprehensive update. J Clin Transl Hepatol 2016;4 (2):131-42

7. Gum S II, Cho MK. Recent updates on acetaminophen hepatotoxicity: the role of Nrf2 in hepatoprotection. Toxicol Res 2013;29 (3):165-72.

8. Oktavia S, Ifora, Suhatri, Marni S. Uji aktivitas hepatoprotktor ekstrak duan sirih hijau (piper betle Linn.) terhadap kerusakan hati yang diinduksi parasetamol. Jurnal Farmasi Hiega 2017;9 (2):109_ 17.

9. Jarsiah P, Anahita N, Ahad A, M Bagher HS. Hepatotoxicity and ALT/AST enzymes activities change in therapeutics and toxic doses consumption of acetaminophen in rats. Int Biol Biomed J Summer 2017;3 (3): 120-4.

10. Achsan M, Sofro U, Wati DR, Astuti R. Pengaruh pemerian n-acetylcysteine terhadap kadar SGOT dan SGPT pada tikus witar yang diberi parasetamol. Med Hosp 2014;2 (2):78-83.

11. Sarmoko, Endang S. Kenikir (Cosmos caudatus). CCRC Farmasi UGM [serial online] 2010 [cited 2018 Agustus 31]. Available from: URL: HIPERLINK

http://ccrc.farmasi.ugm.ac.id/?page_id=101

12. Made N, Sandhiutami D, Desmiaty Y. Inhibitory effect of lantana camara L ., eclipta prostrata ( L .) L .and cosmos caudatus kunth. Leaf Extracts on ADPInduced Platelet Aggregation. Pharmacogn $J$ 2018;10 (3):581-5.

13.Li C, Zhang WJ, Choi J, Frei B. Quercetin affects glutathione levels and redox ratio in human aortic endothelial cells not through oxidation but formation and cellular export of quercetin-glutathione conjugates and upregulation of glutamate-cysteine ligase. Redox Biol 2016;9 :220-8.

14. Safitri J. Uji aktivitas hepatoprotektor fraksi metanol daun kesum (polygonum minus huds.) pada tikus putih jantan galur wistar yang diinduksi cisplatin. Skripsi. Fakultas Kedokteran Tanjungpura pontianak. 2013.

15.Lopez NL, Gutierrez-Grijalva EP, Ambriz-Perez DL, Basilio HJ. Flavonoids as cytokine modulators: a possible therapy for inflammation-related diseases. Int J Mol Sci 2016;17 (6): 1-15.

16. Mazaleuskaya LL, Sangkuhl K, Thorn CF, Fitzgerald GA, Altman RB, Klein TE. PharmGKB summary: pathways of acetaminophen metabolism at the therapeutic versus toxic doses. Pharmacogenet Genomics 2015;25 (8):416-26.

17. Hinson JA, Roberts DW, James LP. Mechanisms of acetaminophen-induced liver necrosis. Handb Exp Pharmacol 2010; 196: 369-405.

18. McGill, RM., Sharpe MR, Williams CD, Taha M, Curry SC, et al. The mechanism underlying acetaminophen induced hepatotoxicity in humans and mice involves mitochondrial damage and 
nuclear DNA fragmentation. The journal clinical investigation 2012; 122 (4): 1578-83.

19. Nofanni IM, Dwi R. Uji aktivitas hepatoprotektor dan antioksidan fraksi etil asetat daun kenikir (Cosmos caudatus K) pada tikus jantan galur wistar yang diinduksi alkohol. Jurnal KeMaDaSka. 2016: 100-7.

20. Erwin, Chaerul S, Tika P. Uji Hipoglikemik Ekstrak Metanol Daun Majapahit (Crescentia Cujete L.) Terhadap Kadar Glukosa Darah Mencit Jantan. Jurnal Kimia Mulawarman 2012: 9(2): 50-5.

21. Katzung BG, Susan BM, Anthony JT. Farmakologi dasar dan klinik. Ed 12. Vol. 2. EGC 2012; 732-3.

22. Thilakarathna SH, Vasantha Rupasinghe HP. Flavonoid bioavailability and attempts for bioavailability enhancement. Nutrients. 2013;5 (9): 3367-87. 